\title{
Scheduled access alcohol drinking by alcohol-preferring $(P)$ and high-alcohol-drinking (HAD) rats: modeling adolescent and adult binge-like drinking
}

\author{
Richard L. Bell, Ph.D. ${ }^{a,}{ }^{\star}$, Zachary A. Rodd, Ph.D. ${ }^{a}$, Eric A. Engleman, Ph.D. ${ }^{a}$, Jamie E. \\ Toalston, Ph.D. ${ }^{a}$, and William J. McBride, Ph.D. ${ }^{a}$ \\ anstitute of Psychiatric Research, Department of Psychiatry, Indiana University School of \\ Medicine, Indianapolis, IN 46202
}

\begin{abstract}
Binge alcohol drinking continues to be a public health concern among today's youth and young adults. Moreover, an early onset of alcohol use, which usually takes the form of binge drinking, is associated with a greater risk for developing alcohol use disorders. Given this, it is important to examine this behavior in rat models of alcohol abuse and dependence. Toward that end, the objective of this article is to review findings on binge-like drinking by selectively bred alcoholpreferring $(\mathrm{P})$ and high-alcohol-drinking (HAD) lines of rats. As reviewed elsewhere in this special issue, the $\mathrm{P}$ line meets all, and the HAD line meets most, of the proposed criteria for an animal model of alcoholism. One model of binge drinking is scheduled ethanol access during the dark cycle, which has been used by our laboratory for over 20 years. Our laboratory has also adopted a protocol involving the concurrent presentation of multiple ethanol concentrations. When this protocol is combined with limited access, ethanol intake is maximized yielding blood ethanol levels (BELs) in excess, sometimes greatly in excess, of $80 \mathrm{mg} \%$. By extending these procedures to include multiple scheduled ethanol access sessions during the dark cycle for 5 consecutive days/ week, $\mathrm{P}$ and $\mathrm{HAD}$ rats consume in 3 or $4 \mathrm{~h}$ as much as, if not more than, the amount usually consumed in a 24-h period. Under certain conditions, using the multiple scheduled access procedure, BELs exceeding $200 \mathrm{mg} \%$ can be achieved on a daily basis. An overview of findings from studies with other selectively bred, inbred, and outbred rats places these findings in the context of the existing literature. Overall, the findings support the use of P and HAD rats as animal models to study binge-like alcohol drinking and reveal that scheduled access procedures will significantly increase ethanol intake by other rat lines and strains as well.
\end{abstract}

(C) 2013 Elsevier Inc. All rights reserved.

*Corresponding author: Richard L. Bell, Ph.D., Institute of Psychiatric Research, Department of Psychiatry, Indiana University School of Medicine, Indianapolis, IN 46202 USA, Telephone: +1 317278 8407, Fax: +1 317274 1365, ribell@iupui.edu.

Disclaimer

The authors do not have real or perceived conflicts of interest associated with the content of this article. The views expressed in this article do not necessarily represent the opinions of the National Institutes of Health (NIH) or the National Institute on Alcohol Abuse and Alcoholism (NIAAA).

Publisher's Disclaimer: This is a PDF file of an unedited manuscript that has been accepted for publication. As a service to our customers we are providing this early version of the manuscript. The manuscript will undergo copyediting, typesetting, and review of the resulting proof before it is published in its final citable form. Please note that during the production process errors may be discovered which could affect the content, and all legal disclaimers that apply to the journal pertain. 


\section{Keywords}

animal model of alcoholism; blood alcohol concentration; discrete bout; drinking-in-the-dark; excessive intake; extreme drinking; limited access; loss-of-control drinking; nocturnal drinking

\section{Introduction}

A majority of adult Americans have a family member with an alcohol use disorder (AUD)

(Research Society on Alcoholism, 2009). Moreover, close to half of adults in the US meeting life-time diagnostic criteria for alcohol dependence do so by the age of 21 , and this percentage increases to approximately two-thirds by the age of 25 (Hingson, Hereen, \& Winter, 2006). Today's youth are initiating alcohol use earlier and experiencing more alcohol-related problems than ever before (Bava \& Tapert, 2010; Gore et al., 2011; Miller, Naimi, Brewer, \& Jones, 2007; Miller, Turner, \& Marlatt, 2001; Pitkänen, Lyyra, \& Pulkkinen, 2005; Quine \& Stephenson, 1990; Winters, 2001). Also, approximately 80\% of US high school seniors have consumed alcohol, with half initiating drinking before the 8th grade (Johnston, O’Malley, \& Bachman, 1999). This is alarming since an early onset of alcohol use is a predisposing factor for developing alcohol dependence (Anthony \& Petronis, 1995; Chou \& Pickering, 1992; Clark, Kirisci, \& Tarter, 1998; Grant \& Dawson, 1997; Hawkins et al., 1997).

Binge alcohol drinking (defined in general terms as consuming 4-5 drinks in $~ 2$-h period and achieving blood ethanol levels of $80 \mathrm{mg} \%$ or more (NIAAA, 2004) appears to be a behavior primarily engaged in by adolescents and young adults ( $<24$ years old) compared with older adults (c.f., Courtney \& Polich, 2009; Marczinski, Grant, \& Grant, 2009; Martinic \& Measham, 2008; Plant \& Plant, 2006). In the US, close to $30 \%$ of high school seniors engage in binge drinking (Johnston, O'Malley, \& Bachman, 1991, 1993), with 70\% of college students having engaged in this behavior during high school (Wechsler, Lee, Kuo, $\&$ Lee, 2000). It has been estimated that greater than 1 out of 3 male college students in the US engage in binge drinking and that a significant proportion of these achieve blood alcohol concentrations (BACs) between 100 and 200 mg\% (e.g., Wechsler, Lee, Kuo, \& Lee, 2000; White, Kraus, \& Swartzwelder, 2006). The seriousness of this problem is underscored by the fact that adolescents drink 11 percent of all alcohol consumed in the US, with practically all of it consumed in the form of binge drinking (NIAAA, 2012). As discussed by L.P. Spear (2010), along with Bell and colleagues (2013), parallel developmental ages between rats and humans have been estimated (estimated body weights are included for rats in Table 1, because most rat studies do not give the animal's age) using behavioral and neurobiological milestones—see Table 1.

\section{Usefulness of selectively bred animal models to study alcohol-associated effects}

Animal models have been successfully used to investigate the causes of, and develop treatments for, medical and psychiatric disorders (e.g., Griffin, 2002; McKinney, 2001; Nestler \& Hyman, 2010). An animal model has the advantage of allowing the experimenter to control factors such as genetic background, environment, and prior drug exposure. Bidirectional selective breeding is a powerful genetic tool for studying many alcohol- 
associated phenotypes (e.g., Crabbe, 2008). Thus, this breeding strategy results in the expression of high vs. low levels of a particular phenotype, such as alcohol intake and/or preference. With this method, the expression levels of a selected phenotype tend to exceed the range of expression displayed by the foundation stock. The alcohol-preferring $\mathrm{P}$ and high alcohol-drinking HAD (replicate 1 and 2) rat lines were selectively bred (from a closed colony of Wistar rats and the N/NIH line, respectively) to prefer a $10 \%$ alcohol solution over water and consume greater than $5 \mathrm{~g}$ of alcohol/kg body weight/day (see McBride, Rodd, Bell, Lumeng, \& Li, 2013b). These selectively bred rats have been used to investigate the effects of continuous (24-h/day) and/or binge alcohol drinking across peri-adolescence and adulthood.

\section{Free-choice 24-h ethanol drinking by $P$ and HAD rats}

Early work indicated that $\mathrm{P}$ rats, when given continuous $24-\mathrm{h}$ access to ethanol $(10 \% \mathrm{v} / \mathrm{v})$ and water in their home cages, consumed most of their ethanol in discrete bouts $(\sim 1 \mathrm{~g} / \mathrm{kg}$ in less than $1 \mathrm{~h}$; resolution was limited to 1 -h observations in this study) during the dark cycle (Murphy et al., 1986). These authors also reported that animals with larger bouts tended to have fewer bouts per day. In this same study, it was shown that bout number and size could be manipulated by giving P rats a single 4-h access session/day vs. 24-h continuous access or four 1-h access sessions/day, such that the largest bout size occurred under the 4-h access session, but, again with fewer bouts (Murphy et al., 1986). However, when total ethanol intake was averaged per hour, the four 1-h access sessions/day group drank the most ethanol $(\sim 1 \mathrm{~g} / \mathrm{kg} / \mathrm{h})$ which was 4 times that of the $24-\mathrm{h}$ and $2 \frac{1}{2}$ times that of the 4-h groups (Table 2).

In a subsequent study, Bell et al. (2006a, b) examined patterns of daily ethanol (15\% v/v) intake by adolescent and adult, male and female $\mathrm{P}$ rats in their home cages using a lickometer setup, such that total licks on the water and ethanol bottles were recorded every 6 min across $22 \mathrm{~h}$ (12 h dark and $10 \mathrm{~h}$ light) for 4 weeks. These studies (Bell et al., 2006a, b) replicated the finding that $\mathrm{P}$ rats drink ethanol in bouts $(\sim 1 \mathrm{~g} / \mathrm{kg} / 6-\mathrm{min})$ during the dark cycle. In addition, these studies confirmed that, in general, animals that consumed larger bouts (often $\sim 2 \mathrm{~g}$ or greater $/ \mathrm{kg} / 6-12 \mathrm{~min}$ ) displayed fewer bouts per $24 \mathrm{~h}$. Regarding periadolescence, late pubertal $\mathrm{P}$ rats engaged in significantly more bouts/day than their adult counterparts, with an associated decrease in the amount of ethanol consumed/bout. A recent study by Dhaher et al. (2012) used the lickometer setup to examine patterns of daily ethanol $(15 \% \mathrm{v} / \mathrm{v})$ intake of adolescent and adult, male and female HAD1 and HAD2 rats. As with the $\mathrm{P}$ rats, HAD rats consume most of their ethanol during the dark cycle and in discrete bouts with the vast majority of these bouts being captured within respective 6-min recording windows. Also comparable with P rats, animals that consumed larger bouts (often $\sim 2 \mathrm{~g}$ or greater $/ \mathrm{kg} / 6$ to $12 \mathrm{~min}$ bin) generally displayed fewer bouts per $24 \mathrm{~h}$. Again, similar to $\mathrm{P}$ rats, late pubertal HAD1 and HAD2 rats engaged in significantly more bouts/day than their adult counterparts, with an associated decrease in the amount of ethanol consumed/bout (Table 2).

This research (Bell et al., 2006a, b; Murphy et al., 1986) indicates that P rats display repeated bouts (approximately equal to or greater than $1 \mathrm{~g} / \mathrm{kg}$ in less than $6 \mathrm{~min}$ ) of alcohol 
intake and these occur primarily during the dark cycle. Similarly, HAD rats consume most of their ethanol during the dark cycle in bouts approximating $2 \mathrm{~g} / \mathrm{kg}$ in less than $6 \mathrm{~min}$ (Dhaher, McConnell, Rodd, McBride, \& Bell, 2012; Table 2). These levels of alcohol intake within this relatively short time span result in BELs of $80 \mathrm{mg} \%$ or higher (Bell et al., 2006a, 2008, 2011). These apparent line differences (Table 2) have been reported elsewhere as well (Files, Samson, Denning, \& Marvin, 1998; Samson, Files, Denning, \& Marvin, 1998; c.f., Bell et al., 2012). However, even though $P$ and HAD rats consume ethanol in discrete bouts during the dark cycle, the timing of these bouts varies between animals and across days. Therefore, to repeatedly capture these binge-like levels of ethanol intake and their associated elevated BELs, a multiple-scheduled-access procedure during the dark cycle has been adopted by our laboratories. This procedure was developed from past findings when a single-scheduled-access procedure was used.

\section{Free-choice scheduled access ethanol drinking by $P$ and HAD rats}

Scheduled access ethanol drinking has been studied with $\mathrm{P}$ and HAD rats, using different durations of access and different concentrations of ethanol solutions, as well as home-cage vs. operant access conditions (Table 3 ). In our laboratory, all of the studies were conducted during the dark cycle, with ethanol intakes satisfying criteria for binge drinking such that BELs of $80 \mathrm{mg} \%$ or higher are regularly achieved (NIAAA, 2004). An initial home-cage study (Murphy et al., 1986) examined free-choice drinking of $10 \%$ ethanol vs. water using a $4 \mathrm{~h} /$ day access protocol. These authors reported that ethanol intakes of adult male $\mathrm{P}$ rats approximated $2 \mathrm{~g} / \mathrm{kg} / \mathrm{session}$. However, most of the ethanol was consumed within the first $15 \mathrm{~min}$, which resulted in average peak BELs reaching $120 \mathrm{mg} \%$ (Table 3). Similar to male $\mathrm{P}$ rats, adult female $\mathrm{P}$ rats consume $2-3 \mathrm{~g} / \mathrm{kg} / 4-\mathrm{h}$ of $10 \%$ ethanol (vs. water) under limitedaccess home-cage conditions (McKinzie et al., 1998a).

Other work has shown that both male $\mathrm{P}$ and male HAD rats will consume $2-3 \mathrm{~g} / \mathrm{kg}$ of $10 \%$ ethanol during a 4-h access period in their home cages, even when $0.0125 \%$ saccharin is concurrently available (Russell, McBride, Lumeng, Li, \& Murphy, 1996). Again, both rat lines consumed the majority of the $10 \%$ ethanol solution within the first 15 min, whereas most of the saccharin intake occurred after the first hour of access. These results indicate that both $\mathrm{P}$ and HAD rats will exhibit binge-like alcohol intakes even when a highly palatable solution is concurrently available. In addition, these rat lines appear to consume ethanol for its CNS pharmacological effects because the pattern of drinking produced BELs exceeding binge criterion levels (i.e., $80 \mathrm{mg} \%$ ) within the first hour. However, a study about this time indicated that a $30-\mathrm{min} /$ day operant access protocol (10\% ethanol vs. water) produced meaningful ethanol intakes in HAD2, but not P or HAD1, lines (Files, Samson, Denning, \& Marvin, 1998). The low intakes in this study (Files, Samson, Denning, \& Marvin, 1998) could be a result of experiments being conducted during the light cycle. A subsequent study examining both home-cage and operant procedures, with 2-h/day access sessions, reported ethanol intakes $\sim 2 \mathrm{~g} / \mathrm{kg} / 2$-h by female $\mathrm{P}$ rats under either condition (Nowak, McKinzie, McBride, \& Murphy, 1999).

Most operant ethanol self-administration studies are undertaken using fixed-schedule access conditions. Such operant studies would qualify as models of binge-like drinking if the self- 
administration results in BELs of $80 \mathrm{mg} \%$ or higher (NIAAA, 2004). More recent operant studies have examined ethanol intake when access is limited to a single $1 \mathrm{~h} /$ day session. When examining ethanol $(15 \% \mathrm{v} / \mathrm{v})$ intake using a standard 2-lever operant procedure with schedules of reinforcement being ethanol $=$ fixed ration 5 (FR5) and water $=$ fixed ratio 1 (FR1), male P rats consumed $\sim 1.3 \mathrm{~g} / \mathrm{kg} / \mathrm{h}$ (Rodd et al., 2003), male HAD1 rats consumed $\sim 1.2 \mathrm{~g} / \mathrm{kg} / \mathrm{h}$ (Oster et al., 2006) and male HAD2 rats consumed $\sim 1.6 \mathrm{~g} / \mathrm{kg} / \mathrm{h}$ (Oster et al., 2006). A study examining the effect of changing the 2 nd lever from water to $0.0125 \%$ saccharin (FR1) revealed male P rats still consumed $\sim 1.3 \mathrm{~g} / \mathrm{kg} / \mathrm{h}$ (Toalston et al., 2008). Similar to the Russell et al. (1996) study, this last finding indicates P rats will continue to self-administer significant amounts of ethanol in the presence of a highly palatable alternative solution.

Subcutaneous (s.c.) ethanol levels have also been examined under limited ( $1 \mathrm{~h} /$ day) access conditions (Engleman et al., 2008). These authors reported that adult $\mathrm{P}$ rats consumed $\sim 1$ $\mathrm{g} / \mathrm{kg} / 1$-h session and s.c. ethanol levels paralleled, albeit at significantly lower levels, BELs. In agreement with previous work, $\mathrm{P}$ rats drank the majority of ethanol in the first 5 min of the session. BELs increased steadily across the 1-h access session and peaked at approximately $50 \mathrm{mg} \%$ at the end of the session. Ethanol levels decreased gradually over the following $3 \mathrm{~h}$, indicating an extended time course of measurable systemic ethanol levels. In addition, the operant technique has been adapted to study the co-abuse of ethanol and nicotine using 1-h/day access to mimic binge-like drinking and smoking conditions (Hauser et al., 2012). Concurrent access to multiple concentrations of ethanol (10,20, and 30\%) was used because this results in higher ethanol intakes than when a single ethanol concentration is presented (e.g., Bell et al., 2003, 2004). Each ethanol solution also contained $0.14 \mathrm{mg} / \mathrm{mL}$ nicotine. This study used a 3-lever operant chamber (each lever allowed the presentation of its respective solution on an FR5 schedule), with water available ad libitum via a water bottle. Under these conditions, adult female P rats consumed $\sim 2 \mathrm{~g} / \mathrm{kg} / \mathrm{session}$ ethanol and $\sim 2$ $\mathrm{mg} / \mathrm{kg} / \mathrm{session}$ nicotine to produce BELs approximating $80 \mathrm{mg} \%$ and blood nicotine levels (BNLs) approximating $50 \mathrm{ng} / \mathrm{mL}$. These BELs and BNLs represent values regularly achieved by binge drinkers and chronic smokers.

In summary, these results with scheduled access drinking illustrate the utility of using $\mathrm{P}$ and HAD rats to study binge-like alcohol drinking, under both home-cage and operant conditions. In addition, the results further illustrate that ethanol is more rewarding than saccharin, and that these selectively bred rats can be used to study the co-abuse of ethanol and nicotine.

\section{Free-choice multiple-scheduled-access ethanol drinking by $P$ and HAD rats}

Thus far, limited-access and 24-h access procedures have provided some information on the acute pharmacological interference of ethanol drinking (see Bell et al., 2012 for a comprehensive review of studies conducted in alcohol-preferring rat lines). However, it is our contention that rat protocols employing a single limited access session per day do not validly address human binge-drinking. This stems from the facts that a) human binge drinking occurs primarily during adolescence and early adulthood, b) human binge drinking is a repetitive phenomenon, such that this type of drinking is engaged in several, or more, 
times a month, and c), as noted in Table 1, in the strictest sense the developmental windows for rat adolescence and peri-adolescence are only 2 weeks each. Further complicating the development of an animal model of binge-like drinking is the fact that a generally accepted clinical definition of this phenomenon (NIAAA, 2004) is a relatively recent occurrence. For instance, the NIAAA definition (2004) of binge drinking (a time frame of $2 \mathrm{~h}$ ) differentiates it from bender-like drinking (a time frame of 2 or more days). Earlier clinical definitions did not always make this distinction, with the number of these instances increasing as one retrospectively examines the literature (c.f., Plant \& Plant, 2006). In addition, despite its general acceptance, there is still some controversy over the $4 / 5$ rule of the NIAAA definition (2004; for some pros and cons see Goldman, 2006; Wechsler \& Nelson, 2006; White, Kraus, \& Swartzwelder, 2006).

On the other hand, as reviewed by Bell and colleagues (2013), a generally accepted basic research definition of binge drinking is still lacking. This lack of consensus stems from the three points about binge drinking research mentioned above and the fact that most rats, as discussed below, do not readily consume sufficient ethanol to achieve pharmacologically relevant BELs, which means they certainly do not achieve binge-associated BELs (i.e., $\geq 80$ $\mathrm{mg} \%$ ). Therefore, our laboratory has sought to examine binge-like drinking using a) selectively bred alcohol-preferring rats, b) a multiple, rather than a single, scheduled-access procedure, c) concurrently available multiple ethanol concentrations, and d) ethanol presentation during the dark phase. The use of selectively bred alcohol-preferring rats ( $\mathrm{P}$ and HAD) capitalizes on their innate proclivity to consume large amounts of ethanol. The use of multiple scheduled-access sessions allows a researcher to capitalize on repeated discrete bouts of ethanol-drinking per day. And, the use of concurrently available multiple ethanol concentrations as well as access during the dark phase capitalizes on significant increases in intake induced by these procedural manipulations. We believe that the combination of these four factors results in an animal model of binge-like drinking with construct and face validity relative to the human condition. Regarding the repetitive nature of binge drinking, it is noteworthy that other animal models of binge-like drinking, which use forced ethanol exposure, also incorporate multiple exposures per day (e.g., Zahr et al., 2013). In general, the findings described below indicate that exposure of high alcohol-consuming rats to multiple free-choice, scheduled-access sessions across the dark cycle results in daily ethanol intake levels approximating, and sometimes exceeding, that seen when these rats are given 24-h free-choice access, producing BELs $\geq 80 \mathrm{mg} \%$.

A study examining the effect of two 1-h ethanol (15 and 30\% available concurrently) access periods during the dark cycle ( 5 days/week) on intake by adult male $\mathrm{P}$ rats revealed average intakes of $2.5 \mathrm{~g} / \mathrm{kg} / \mathrm{h}$ and average BELs of $120 \mathrm{mg} \%$ at the end of the 1-h session, which would not represent peak BELs (Bell, Rodd, Lumeng, Murphy, \& McBride, 2006a).

Moreover, $\sim 60 \%$ of the ethanol was consumed in the first 6 min with $\sim 95 \%$ of the ethanol consumed within the first $12 \mathrm{~min}$. In a parallel study (Bell et al., 2006c), adult female inbred $\mathrm{P}$ (iP) rats were given four 1-h free-choice ethanol (15 and 30\%) access periods across the dark cycle. This study (Bell et al., 2006c) revealed that four 1-h access periods yielded greater initial ethanol intake by the binge-like access group compared with a continuous access ( $24 \mathrm{~h} / 7$ days/week) group (peak intakes were $8 \mathrm{~g} / \mathrm{kg} /$ day and $6 \mathrm{~g} / \mathrm{kg} / \mathrm{day}$, respectively). Results from these studies indicated that whereas multiple $1-\mathrm{h}$ access periods 
across the dark cycle result in ethanol intakes of $1.5 \mathrm{~g} / \mathrm{kg} / \mathrm{h}$ or higher, with peak BELs regularly exceeding $100 \mathrm{mg} \%$, there is a point of diminishing returns, such that more access periods are not always better (Table 4).

Another study (Bell, Rodd, Lumeng, Murphy, \& McBride, 2006a) indicated that three 1-h ethanol access periods, each separated by $2 \mathrm{~h}$, may maximize ethanol intake in adult male $\mathrm{P}$ rats. Thus, our laboratory set out to characterize binge-like ethanol drinking by periadolescent and adult, male and female $\mathrm{P}$ rats using a multiple-scheduled-access procedure that involved three 1-h access periods across the dark cycle (Bell et al., 2011). Using this procedure it was found that, during a 1-h access period, ethanol intake by adolescent [postnatal day (PND) 45 or 47] male P rats climbed from $1.7 \mathrm{~g} / \mathrm{kg}$ at $15 \mathrm{~min}$ to $2.7 \mathrm{~g} / \mathrm{kg}$ at 60 min, with BELs climbing from $\sim 60 \mathrm{mg} \%$ at $15 \mathrm{~min}$ to $100 \mathrm{mg} \%$ at 30 and $60 \mathrm{~min}$ (Bell et al., 2011). In addition, intoxication was evaluated, with an oscillating bar task (c.f., Bell et al., 2000, 2001), in adult female P rats. Binge-drinking rats displayed significantly shorter latencies to fall during the 4th, but not 1st, week of ethanol access compared with water controls, despite no difference in latency to fall between the 1st- and 4th-week binge drinkers. Moreover, ethanol intake increased from $\sim 1.5$ to $\sim 2.25 \mathrm{~g} / \mathrm{kg} / \mathrm{h}$ and BELs increased from $\sim 35$ to $\sim 75 \mathrm{mg} \%$ across weeks. These latter results suggest the development of tolerance across the 4 weeks of multiple-scheduled-access to ethanol. The intoxicating effects of binge-like drinking by peri-adolescent female $\mathrm{P}$ rats were also examined, again using latency to fall in the oscillating bar task (Bell et al., 2011). Binge-drinking rats displayed significantly shorter latencies to fall vs. same-aged water controls ( $\sim 80 \mathrm{sec}$ vs. 120 $\mathrm{sec}$, respectively). In addition, average ethanol intake by the binge-drinkers was $\sim 3 \mathrm{~g} / \mathrm{kg} / 30$ min with $\sim 90 \mathrm{mg} \%$ average BELs detected after the test for intoxication.

These results support the contention that the multiple-scheduled-access procedure can be used to model binge-like drinking. For instance, this type of drinking results in the regular occurrence of $80 \mathrm{mg} \%$ [the threshold BEL in NIAAA's (2004) definition for binge drinking] and motor impairment as a measure of intoxication (Bell et al., 2006a, 2011). These benchmarks were achieved in both peri-adolescent and adult $\mathrm{P}$ rats of both sexes. Moreover, the findings (Bell et al., 2011) provide some "face" validity for this developmental bingedrinking model, such that peri-adolescent rats consumed more alcohol than their adult counterparts both in terms of total consumption per day and consumption per 1-h access period. Also, whereas adult $\mathrm{P}$ rats given continuous access consumed more alcohol than those given binge-like access, the reverse was true for peri-adolescent $\mathrm{P}$ rats, with binge-like access animals consuming significantly more ethanol each day than their continuous access counterparts.

The multiple-scheduled-access procedure can also be used with operant protocols (e.g., McBride et al., 2013a; Warnock et al., 2012). For instance, using a 3-lever operant procedure with concurrent access to 10,20, and $30 \%$ ethanol and four 1-h daily access sessions, it has been shown that adult female P rats self-administer 1.2 to $1.7 \mathrm{~g} / \mathrm{kg} / 1-\mathrm{h}$ session and attain BELs greater than $200 \mathrm{mg} \%$ (McBride et al., 2013a). Such high BELs are associated with profound intoxication, are dangerous, and suggest that this procedure can induce loss-of-control drinking. Therefore, this procedure offers a model for determining alterations in neurocircuitry responsible for the loss of an ability to control/limit a person's 
drinking. Additionally, the multiple-scheduled-access procedure produces ethanol intakes and BELs that reliably exceed binge levels on a daily basis in both adult and peri-adolescent $P$ rats.

\section{Ethanol-drinking behavior of other rat lines}

There are several other selectively bred, alcohol-preferring rat lines in the world, which meet the general criteria of consuming at least $5 \mathrm{~g} / \mathrm{kg} /$ day of ethanol and exhibiting a clear preference for $10 \%$ ethanol over water. The ALKO Accepting/alcohol-preferring AA rat line was developed from a closed colony of Wistar-Sprague-Dawley cross foundation stock in Helsinki, Finland (Eriksson, 1968). The Sardinian alcohol-preferring sP rats were developed from a local Wistar foundation stock at the University of Cagliari, Italy (Colombo, Lobina, Carai, \& Gessa, 2006). The alcohol-preferring University of Chile B UChB line of rat was developed from a local Wistar foundation stock at the University of Chile, Santiago, Chile (Mardones \& Segovia-Riquelme, 1983). And, more recently, the alcohol-preferring Warsaw High Preferring WHP line was developed from a local Wistar foundation stock at the Institute of Psychiatry and Neurology in Warsaw, Poland (Bisaga \& Kostowski, 1993). In addition, the High 'Addiction Research Foundation' HARF rat was selectively bred at the Center for Addiction and Mental Health in Toronto, Ontario, Canada, to consume considerable amounts of ethanol when given 20 min of access per day ( $\geq 1 \mathrm{~g} / \mathrm{kg} / 20$-min, $>6$ g/kg/day; Lê, Israel, Juzytsch, Quan, \& Harding, 2001). The HAD replicate and HARF rat lines were selectively bred from the N/NIH foundation stock (a cross of 8 inbred rat strains with varying levels of ethanol intake; Hansen $\&$ Spuhler, 1984). Of the international selectively bred alcohol-preferring rat lines, the majority of the pharmacology and neurobiology of alcohol preference/consumption research has been conducted in the AA, HAD replicate, P, sP, and UChB lines (see Bell et al., 2012; also see Sommer, Hyytiä, Kiianmaa, 2006; Colombo, Lobina, Carai, \& Gessa, 2006; Quintanilla, Israel, Sapag, \& Tampier, 2006 for earlier reviews on the AA, sP, and UChB lines, respectively). Table 5 outlines the 24-h ethanol-drinking levels displayed by these and other rat lines and experimental manipulations used to achieve these levels of intake (e.g., intermittent access where the rats are given 24-h, free-choice access to $20 \%$ ethanol vs. water Monday, Wednesday, and Friday of each week). Table 6 outlines the levels of limited access ethanol consumption displayed by these and other rat lines along with associated experimental manipulations (e.g., the limited access session is presented during the dark/nocturnal/active cycle for rats).

Still, other rat lines have also been used to examine the pharmacology and neurobiology of ethanol drinking and self-administration (see Tables 5 and 6). Three such rat lines are derivatives of previously selected rat lines, such that the High Ethanol Preferring (HEP) line was derived from the $P$ line (Myers, Robinson, West, Biggs, \& McMillen, 1998), the Cologne AA (cAA) line was derived from the AA line (Maurel, De Vry, De Beun, \& Schreiber, 1999), and the Marchigian sP (msP) was derived from the sP line (Ciccocioppo et al., 2006). These lines like their progenitors consume $>5 \mathrm{~g} / \mathrm{kg} /$ day of ethanol and display a clear ethanol (11\% or 10\%) preference over water. The inbred Fawn Hooded rat, whether from a vendor in the United States or France, consumes $\sim 4 \mathrm{~g} / \mathrm{kg} /$ day of ethanol with a modest preference for $10 \%$ ethanol over water (Overstreet, Rezvani, Cowen, Chen, \& 
Lawrence, 2006; Femenia, García-Gutiérrez, \& Manzanares, 2010, respectively). In addition, some rat lines selectively bred for a different behavioral phenotype display modest to relatively high ethanol intakes per day. For instance, Maudsley Reactive (MR/Har) rats consume close to $4 \mathrm{~g} / \mathrm{kg} /$ day of ethanol with a $60 \%$ preference for $10 \%$ ethanol over water (Adams, Mitchell, Campbell, \& Samson, 2002). Unlike the alcohol-preferring vs. alcoholnonpreferring rat lines, their Maudsley Non-Reactive (MNR/Har) counterparts consume close to the same amounts of ethanol, $\sim 3.5 \mathrm{~g} / \mathrm{kg} / \mathrm{day}$ and a $50 \%$ preference for ethanol over water (Adams, Mitchell, Campbell, \& Samson, 2002). Another example is the Taste Aversion Resistant (TAR) rat line, which consumes $>5 \mathrm{~g} / \mathrm{kg} /$ day of ethanol (Orr, WhitfordStoddard, \& Elkins, 2004). Similar to selectively bred alcohol-nonpreferring rats, Taste Aversion Prone (TAP) rats (the TAR counterpart), consume very little ethanol (Orr, Whitford-Stoddard, \& Elkins, 2004).

Finally, outbred rat lines have also been used to investigate the pharmacology and neurobiology of ethanol reward and reinforcement (see Tables 5 and 6). The 2 primary outbred rat lines displaying appreciable levels of ethanol intake, although they require experimental manipulations to achieve the levels described above, are the Wistar and LongEvans Hooded lines. Note that Wistar lineage is found in all of the selectively bred rat lines achieving pharmacologically relevant BECs. The Sprague-Dawley rat line has been used, but in general this line displays significantly lower ethanol intakes than the Wistar and Long-Evans Hooded lines. Only a few examples are presented in Tables 5 and 6 and these studies included experimental manipulations (described therein) that resulted in ethanol intakes significantly greater than levels seen in experimentally naïve rats of these same lines. For instance, when employing an alcohol deprivation effect protocol, Wistar rats can consume close to $4.5 \mathrm{~g} / \mathrm{kg} / \mathrm{day}$ of ethanol (Sinclair \& Li, 1989). Other work has demonstrated that when giving Wistar and Long-Evans Hooded rats intermittent (Monday, Wednesday, and Friday) 24-h, free-choice access to $20 \%$ ethanol, these lines will consume $\geq$ $5 \mathrm{~g} / \mathrm{kg} /$ day achieving 50 to $60 \mathrm{mg} \%$ BEC levels $45 \mathrm{~min}$ into the dark cycle (Simms et al., 2008). When given limited access, outbred rats rarely display ethanol intakes approaching 1 $\mathrm{g} / \mathrm{kg} / \mathrm{h}$. However, experimental manipulations including fading or adaptation procedures (e.g., Czachowski, Santini, Legg, \& Samson, 2002) have resulted in Wistar rats consuming greater than $1.5 \mathrm{~g} / \mathrm{kg} / 2-\mathrm{h}$ (Bono, Balducci, Richelmi, Koob, \& Pulvirenti, 1996) and LongEvans Hooded rats consuming $\sim 0.7 \mathrm{~g} / \mathrm{kg} / 20$-min and achieving $\sim 65 \mathrm{mg} \%$ BELs (Czachowski, Santini, Legg, \& Samson, 2002). Interestingly, using the same procedures of Czachowski et al. (2002), Czachowski and Samson (2002) reported that P, HAD1, and HAD2 rats consume between 1 and $1.5 \mathrm{~g} / \mathrm{kg} / 20$ - min, with no significant line differences in intake.

\section{Conclusion}

In summary, these findings indicate that the selectively bred P, HAD1, and HAD2 rat lines display a pattern of higher ethanol intakes and bouts of drinking during the dark period of the light-dark cycle. Even under 24-h free-choice drinking conditions, these rat lines regularly consume sufficient amounts of ethanol to produce pharmacologically relevant BELs. Furthermore, under scheduled access (binge-like) conditions during the dark phase, $\mathrm{P}$ and HAD rats consistently drink enough ethanol to meet criteria for binge drinking, such as 
BELs greater than $80 \mathrm{mg} \%$ and the expression of intoxication. In addition, these rat lines will continue to engage in binge-like drinking even when a highly palatable alternative solution is present. The scheduled-access procedure can also be used to study the co-abuse of ethanol and other addictive compounds. For instance, this procedure results in binge-like BELs concurrently with blood nicotine levels equivalent to those seen in chronic smokers. When the scheduled-access procedure is modified to include multiple access periods across the dark cycle and the concurrent presentation of multiple ethanol concentrations, BELs 2-3 times the binge criterion threshold can be achieved, suggesting the presence of loss-ofcontrol drinking. To provide some context for these findings from the $\mathrm{P}$ and HAD replicate lines, a limited number of ethanol drinking studies using other lines of rats were also presented.

These studies, on rat lines besides the $\mathrm{P}$ and HAD replicate lines, indicate that selective breeding for alcohol-preference results in rat lines that readily consume ethanol to the point of intoxication. Selective breeding for other behavioral phenotypes may also result in appreciable levels of ethanol intake, but these intakes rarely result in BELs that meet the standard definition of binge-like drinking (i.e., $\geq 80 \mathrm{mg} \%$ ). Similarly, inbred rat lines may display modest-to-high ( $\sim \mathrm{g} / \mathrm{kg} / \mathrm{day}$ ) levels of ethanol intake but, once again, these intakes seldom result in BELs ascribed to binge-like drinking. Finally, without experimental manipulations, outbred rats rarely display ethanol intakes that approach half (i.e., $2.5 \mathrm{~g} / \mathrm{kg} /$ day) of the ethanol intake criterion used to selectively breed for an alcohol preference. However, this review highlighted some experimental manipulations (e.g., access during the dark phase, intermittent access, multiple-scheduled-access) that will significantly increase ethanol consumption by all of these selectively bred, inbred, and outbred rat lines.

Moreover, these experimental procedures can be successfully conducted in water-satiated rats providing multiple genetic platforms to examine the neurobiology and pharmacology of alcohol dependence.

\section{Acknowledgments}

Preparation of this manuscript was supported in part by NIH/NIAAA grant AA13522.

\section{References}

Aalto J. Circadian drinking rhythms and blood alcohol levels in two rat lines developed for their alcohol consumption. Alcohol. 1986; 3:73-75. [PubMed: 3964440]

Adams N, Mitchell PS, Campbell SD, Samson HH. Ethanol self-administration in Maudsley reactive and Maudsley nonreactive inbred rats. Alcohol. 2002; 26:155-161. [PubMed: 12057776]

Agabio R, Carai MA, Lobina C, Pani M, Reali R, Vacca G, et al. Development of short-lasting alcohol deprivation effect in Sardinian alcohol-preferring rats. Alcohol. 2000; 21:59-62. [PubMed: 10946158]

Anthony JC, Petronis KR. Early-onset drug use and risk of later drug problems. Drug and Alcohol Dependence. 1995; 40:9-15. [PubMed: 8746919]

Bava S, Tapert SF. Adolescent brain development and the risk for alcohol and other drug problems. Neuropsychology Review. 2010; 20:398-413. [PubMed: 20953990]

Bell, RL.; Franklin, KM.; Hauser, SR.; Engleman, EA. Next stop dependence. Binge drinking on the road to alcoholism: preclinical findings on its neurobiology from rat animal models. In: Harris, SB., editor. Binge eating and binge drinking: Psychological, social and medical implications. New York: Nova Science Publishers; 2013. In Press 
Bell RL, Kimpel MW, Rodd ZA, Strother WN, Bai F, Peper CL, et al. Protein expression changes in the nucleus accumbens and amygdala of inbred alcohol-preferring rats given either continuous or scheduled access to ethanol. Alcohol. 2006c; 40:3-17. [PubMed: 17157716]

Bell RL, McKinzie DL, Murphy JM, McBride WJ. Sensitivity and tolerance to the motor impairing effects of moderate doses of ethanol. Pharmacology, Biochemistry, and Behavior. 2000; 67:583586.

Bell RL, Rodd ZA, Hsu CC, Lumeng L, Li TK, Murphy JM, et al. Effects of concurrent access to a single or multiple concentrations of ethanol on ethanol intake by periadolescent high-alcoholdrinking rats. Alcohol. 2004; 33:107-115. [PubMed: 15528008]

Bell RL, Rodd ZA, Lumeng L, Murphy JM, McBride WJ. The alcohol-preferring P rat and animal models of excessive alcohol drinking. Addiction Biology. 2006a; 11:270-288. [PubMed: 16961759]

Bell RL, Rodd ZA, Sable HJ, Schultz JA, Hsu CC, Lumeng L, et al. Daily patterns of ethanol drinking in peri-adolescent and adult alcohol-preferring $(\mathrm{P})$ rats. Pharmacology, Biochemistry, and Behavior. 2006b; 83:35-46.

Bell RL, Rodd ZA, Schultz JA, Peper CL, Lumeng L, Murphy JM, et al. Effects of short deprivation and re-exposure intervals on the ethanol drinking behavior of selectively bred high alcoholconsuming rats. Alcohol. 2008; 42:407-416. [PubMed: 18486429]

Bell RL, Rodd ZA, Smith RJ, Toalston JE, Franklin KM, McBride WJ. Modeling binge-like ethanol drinking by peri-adolescent and adult $\mathrm{P}$ rats. Pharmacology, Biochemistry, and Behavior. 2011; 100:90-97.

Bell RL, Rodd-Henricks ZA, Kuc KA, Lumeng L, Li TK, Murphy JM, et al. Effects of concurrent access to a single or multiple concentrations of ethanol on the intake of ethanol by male and female periadolescent alcohol-preferring (P) rats. Alcohol. 2003; 29:137-148. [PubMed: 12798969]

Bell RL, Sable HJ, Colombo G, Hyytiä P, Rodd ZA, Lumeng L. Animal models for medications development targeting alcohol abuse using selectively bred rat lines: neurobiological and pharmacological validity. Pharmacology, Biochemistry, and Behavior. 2012; 103:119-155.

Bell RL, Stewart RB, Woods JE 2nd, Lumeng L, Li T-K, Murphy JM, et al. Responsivity and development of tolerance to the motor impairing effects of moderate doses of ethanol in alcoholpreferring (P) and -nonpreferring (NP) rat lines. Alcoholism: Clinical and Experimental Research. 2001; 25:644-650.

Bisaga A, Kostowski W. Selective breeding of rats differing in voluntary ethanol consumption. Polish Journal of Pharmacology. 1993; 45:431-436. [PubMed: 8118485]

Bito-Onon JJ, Simms JA, Chatterjee S, Holgate J, Bartlett SE. Varenicline, a partial agonist at neuronal nicotinic acetylcholine receptors, reduces nicotine-induced increases in $20 \%$ ethanol operant self-administration in Sprague-Dawley rats. Addiction Biology. 2011; 16:440-449. [PubMed: 21392178]

Bono G, Balducci C, Richelmi P, Koob GF, Pulvirenti L. Dopamine partial receptor agonists reduce ethanol intake in the rat. European Journal of Pharmacology. 1996; 296:233-238. [PubMed: 8904074]

Chou SP, Pickering RP. Early onset of drinking as a risk factor for lifetime alcohol-related problems. British Journal of Addiction. 1992; 87:1199-1204. [PubMed: 1511233]

Ciccocioppo R, Economidou D, Cippitelli A, Cucculelli M, Ubaldi M, Soverchia L, et al. Genetically selected Marchigian Sardinian alcohol-preferring (msP) rats: An animal model to study the neurobiology of alcoholism. Addiction Biology. 2006; 11:339-355. [PubMed: 16961763]

Ciccocioppo R, Economidou D, Rimondini R, Sommer W, Massi M, Heilig M. Buprenorphine reduces alcohol drinking through activation of the nociception/orphanin FQ-NOP receptor system. Biological Psychiatry. 2007; 61:4-12. [PubMed: 16533497]

Clark DB, Kirisci L, Tarter RE. Adolescent versus adult onset and the development of substance use disorders in males. Drug and Alcohol Dependence. 1998; 49:115-121. [PubMed: 9543648]

Colombo G, Agabio R, Lobina C, Reali R, Vacca G, Gessa GL. Stimulation of locomotor activity by voluntarily consumed ethanol in Sardinian alcohol-preferring rats. European Journal of Pharmacology. 1998; 357:109-113. [PubMed: 9797025] 
Colombo G, Lobina C, Carai MA, Gessa GL. Phenotypic characterization of genetically selected Sardinian alcohol-preferring (sP) and -non-preferring (sNP) rats. Addiction Biology. 2006; 11:324-338. [PubMed: 16961762]

Courtney KE, Polich J. Binge drinking in young adults: Data, definitions, and determinants. Psychological Bulletin. 2009; 135:142-156. [PubMed: 19210057]

Crabbe JC. Review. Neurogenetic studies of alcohol addiction. Philosophical Transactions of the Royal Society of London. Series B, Biological Sciences. 2008; 363:3201-3211.

Czachowski CL, Samson HH. Ethanol- and sucrose-reinforced appetitive and consummatory responding in HAD1, HAD2, and P rats. Alcoholism: Clinical and Experimental Research. 2002; 26:1653-1661.

Czachowski CL, Santini LA, Legg BH, Samson HH. Separate measures of ethanol seeking and drinking in the rat: Effects of remoxipride. Alcohol. 2002; 28:39-46. [PubMed: 12377359]

Dhaher R, McConnell KK, Rodd ZA, McBride WJ, Bell RL. Daily patterns of ethanol drinking in adolescent and adult, male and female, high alcohol drinking (HAD) replicate lines of rats. Pharmacology, Biochemistry, and Behavior. 2012; 102:540-548.

Dyr W, Kostowski W. Warsaw high-preferring (WHP) and Warsaw low-preferring (WLP) lines of rats selectively bred for high and low voluntary ethanol intake: Preliminary phenotypic characterization. Alcohol. 2008; 42:161-170. [PubMed: 18420111]

Engleman EA, Ingraham CM, Franklin KM, Keith CM, McClaren JA, Schultz JA, et al. In vivo timecourse changes in ethanol levels sampled with subcutaneous microdialysis. Alcoholism: Clinical and Experimental Research. 2008; 32:435-442.

Ericson M, Blomqvist O, Engel JA, Söderpalm B. Voluntary ethanol intake in the rat and the associated accumbal dopamine overflow are blocked by ventral tegmental mecamylamine. European Journal of Pharmacology. 1998; 358:189-196. [PubMed: 9822883]

Eriksson K. Genetic selection for voluntary alcohol consumption in the albino rat. Science. 1968; 159:739-741. [PubMed: 17795073]

Femenía T, García-Gutiérrez MS, Manzanares J. CB1 receptor blockade decreases ethanol intake and associated neurochemical changes in Fawn-Hooded rats. Alcoholism: Clinical and Experimental Research. 2010; 34:131-141.

Files FJ, Samson HH, Denning CE, Marvin S. Comparison of alcohol-preferring and nonpreferring selectively bred rat lines. II. Operant self-administration in a continuous-access situation. Alcoholism: Clinical and Experimental Research. 1998; 22:2147-2158.

Goldman MS. Commentary on White, Kraus, and Swartzwelder (2006): "Many college freshman drink at levels far beyond the binge threshold". Alcoholism: Clinical and Experimental Research. 2006; 30:919-921.

Goodwin FL, Bergeron N, Amit Z. Differences in the consumption of ethanol and flavored solutions in three strains of rats. Pharmacology, Biochemistry, and Behavior. 2000; 65:357-362.

Gore FM, Bloem PJ, Patton GC, Ferguson J, Joseph V, Coffey C, et al. Global burden of disease in young people aged 10-24 years: a systematic analysis. Lancet. 2011; 377:2093-2102. [PubMed: 21652063]

Grant BF, Dawson DA. Age at onset of alcohol use and its association with DSM-IV alcohol abuse and dependence: results from the National Longitudinal Alcohol Epidemiologic Survey. Journal of Substance Abuse. 1997; 9:103-110. [PubMed: 9494942]

Griffin JF. A strategic approach to vaccine development: Animal models, monitoring vaccine efficacy, formulation and delivery. Advances in Drug Delivery Review. 2002; 54:851-861.

Hansen C, Spuhler K. Development of the National Institute of Health genetically heterogeneous rat stock. Alcoholism: Clinical and Experimental Research. 1984; 8:477-479.

Hauser SR, Katner SN, Deehan GA Jr, Ding ZM, Toalston JE, Scott BJ, et al. Development of an oral operant nicotine/ethanol co-use model in alcohol-preferring (P) rats. Alcoholism: Clinical and Experimental Research. 2012; 36:1963-1972.

Hawkins JD, Graham JW, Maguin E, Abbott R, Hill KG, Catalano RF. Exploring the effects of age of alcohol use initiation and psychosocial risk factors on subsequent alcohol misuse. Journal of Studies on Alcohol. 1997; 58:280-290. [PubMed: 9130220] 
Hingson RW, Heeren T, Winter MR. Age at drinking onset and alcohol dependence: Age at onset, duration, and severity. Archives of Pediatric and Adolescent Medicine. 2006; 160:739-746.

Hopf FW, Simms JA, Chang SJ, Seif T, Bartlett SE, Bonci A. Chlorzoxazone, an SK-type potassium channel activator used in humans, reduces excessive alcohol intake in rats. Biological Psychiatry. 2011; 69:618-624. [PubMed: 21195386]

Hyytiä P, Sinclair JD. Demonstration of lever pressing for oral ethanol by rats with no prior training or ethanol experience. Alcohol. 1989; 6:161-164. [PubMed: 2713088]

Ingman K, Salvadori S, Lazarus L, Korpi ER, Honkanen A. Selective delta-opioid receptor antagonist $\mathrm{N}, \mathrm{N}(\mathrm{CH} 3) 2-\mathrm{Dmt}-\mathrm{Tic}-\mathrm{OH}$ does not reduce ethanol intake in alcohol-preferring AA rats. Addiction Biology. 2003; 8:173-179. [PubMed: 12850776]

Janak PH, Michael Gill T. Comparison of the effects of allopregnanolone with direct GABAergic agonists on ethanol self-administration with and without concurrently available sucrose. Alcohol. 2003; 30:1-7. [PubMed: 12878269]

Johnston, LD.; O’Malley, PM.; Bachman, JG. DHHS Publication No ADM 91-1813. Washington, DC: Superintendent of Documents, U.S. Government Printing Office; 1991. Drug use among American high school seniors, college students and young adults, 1975-1990. Volume I. High school seniors.

Johnston, LD.; O’Malley, PM.; Bachman, JG. NIH Publication No 93-3597. Rockville, MD: National Institute on Drug Abuse; 1993. National Survey Results on Drug Use from the Monitoring the Future Study, 1975-1992. Volume I: Secondary school students.

Johnston, LD.; O’Malley, PM.; Bachman, JG. National Survey Results on Drug Use from the Monitoring the Future Study, 1975-1997. Rockville, MD: National Institute on Drug Abuse; 1999.

Landgren S, Engel JA, Hyytiä P, Zetterberg H, Blennow K, Jerlhag E. Expression of the gene encoding the ghrelin receptor in rats selected for differential alcohol preference. Behavioural Brain Research. 2011a; 221:182-188. [PubMed: 21392542]

Landgren S, Simms JA, Hyytiä P, Engel JA, Bartlett SE, Jerlhag E. Ghrelin receptor (GHS-R1A) antagonism suppresses both operant alcohol self-administration and high alcohol consumption in rats. Addiction Biology. 2011b; 17:86-94. [PubMed: 21309944]

Lê AD, Israel Y, Juzytsch W, Quan B, Harding S. Genetic selection for high and low alcohol consumption in a limited-access paradigm. Alcoholism: Clinical and Experimental Research. 2001; 25:1613-1620.

Loi B, Lobina C, Maccioni P, Fantini N, Carai MA, Gessa GL, et al. Increase in alcohol intake, reduced flexibility of alcohol drinking, and evidence of signs of alcohol intoxication in Sardinian Alcohol-Preferring rats exposed to intermittent access to $20 \%$ alcohol. Alcoholism: Clinical and Experimental Research. 2010; 34:2147-2154.

Maccioni P, Zaru A, Loi B, Lobina C, Carai MA, Gessa GL, et al. Comparison of the effect of the $\mathrm{GABAB}$ receptor agonist, baclofen, and the positive allosteric modulator of the GABAB receptor, GS39783, on alcohol self-administration in 3 different lines of alcohol-preferring rats. Alcoholism: Clinical and Experimental Research. 2012; 36:1748-1766.

Marczinski, CA.; Grant, EC.; Grant, VJ. Binge drinking in adolescents and college students. New York: Nova Science Publishers; 2009.

Mardones J, Segovia-Riquelme N. Thirty-two years of selection of rats by ethanol preference: UChA and UChB strains. Neurobehavioral Toxicology and Teratology. 1983; 5:171-178. [PubMed: 6683362]

Martinic, M.; Measham, F. Swimming with crocodiles: The culture of extreme drinking. New York: Routledge/Taylor \& Francis Group; 2008.

Maurel S, De Vry J, De Beun R, Schreiber R. 5-HT2A and 5-HT2C/5-HT1B receptors are differentially involved in alcohol preference and consummatory behavior in cAA rats. Pharmacology, Biochemistry, and Behavior. 1999; 62:89-96.

McBride WJ, Kimpel MW, McClintick JN, Ding ZM, Hauser SR, Edenberg HJ, et al. Changes in gene expression within the ventral tegmental area following repeated excessive binge-like alcohol drinking by alcohol-preferring (P) rats. Alcohol. 2013a; 47:367-380. [PubMed: 23714385]

McBride WJ, Rodd ZA, Bell RL, Lumeng L, Li T-K. The alcohol-preferring $(\mathrm{P})$ and high alcoholdrinking (HAD) rats-Animal models of alcoholism. Alcohol. 2013b This Issue. 
McKinney WT. Overview of the past contributions of animal models and their changing place in psychiatry. Seminars in Clinical Psychiatry. 2001; 6:68-78.

McKinzie DL, Eha R, Cox R, Stewart RB, Dyr W, Murphy JM, et al. Serotonin3 receptor antagonism of alcohol intake: effects of drinking conditions. Alcohol. 1998a; 15:291-298. [PubMed: 9590513]

McKinzie DL, Nowak KL, Yorger L, McBride WJ, Murphy JM, Lumeng L, et al. The alcohol deprivation effect in the alcohol-preferring $\mathrm{P}$ rat under free-drinking and operant access conditions. Alcoholism: Clinical and Experimental Research. 1998b; 22:1170-1176.

Mhatre M, Holloway F. Micro1-opioid antagonist naloxonazine alters ethanol discrimination and consumption. Alcohol. 2003; 29:109-116. [PubMed: 12782252]

Miller JW, Naimi TS, Brewer RD, Jones SE. Binge drinking and associated health risk behaviors among high school students. Pediatrics. 2007; 119:76-85. [PubMed: 17200273]

Miller, ET.; Turner, AP.; Marlatt, GA. The harm reduction approach to the secondary prevention of alcohol problems in adolescents and young adults: considerations across a developmental spectrum. In: Monti, PM.; Colby, SM.; O’Leary, TA., editors. Adolescents, Alcohol, and Substance Abuse: Reaching Teens through Brief Interventions. New York: Guilford Press; 2001. p. 58-79.

Murphy JM, Gatto GJ, McBride WJ, Lumeng L, Li TK. Operant responding for oral ethanol in the alcohol-preferring P and alcohol-nonpreferring NP lines of rats. Alcohol. 1989; 6:127-131. [PubMed: 2713085]

Murphy JM, Gatto GJ, Waller MB, McBride WJ, Lumeng L, Li TK. Effects of scheduled access on ethanol intake by the alcohol-preferring (P) line of rats. Alcohol. 1986; 3:331-336. [PubMed: 3778650]

Myers RD, Robinson DE, West MW, Biggs TA, McMillen BA. Genetics of alcoholism: Rapid development of a new High-Ethanol-Preferring (HEP) strain of female and male rats. Alcohol. 1998; 16:343-357. [PubMed: 9818988]

Nestler EJ, Hyman SE. Animal models of neuropsychiatric disorders. Nature Neuroscience. 2010; 13:1161-1169.

NIAAA. Underage drinking. 2012. NIAAA Fact SheetAvailable at http://pubs.niaaa.nih.gov/ publications/UnderageDrinking/Underage_Fact.pdf Published March 2012

NIAAA National Advisory Council. NIAAA Council approves definition of binge drinking. NIAAA Newsletter. 2004; 3:3.

Nielsen CK, Simms JA, Li R, Mill D, Yi H, Feduccia AA, et al. Delta-opioid receptor function in the dorsal striatum plays a role in high levels of ethanol consumption in rats. The Journal of Neuroscience. 2012; 32:4540-4552. [PubMed: 22457501]

Nowak KL, McKinzie DL, McBride WJ, Murphy JM. Patterns of ethanol and saccharin intake in P rats under limited-access conditions. Alcohol. 1999; 19:85-96. [PubMed: 10487392]

Orr TE, Whitford-Stoddard JL, Elkins RL. Taste-aversion-prone (TAP) rats and taste-aversionresistant (TAR) rats differ in ethanol self-administration, but not in ethanol clearance or general consumption. Alcohol. 2004; 33:1-7. [PubMed: 15353168]

Oster SM, Toalston JE, Kuc KA, Pommer TJ, Murphy JM, Lumeng L, et al. Effects of multiple alcohol deprivations on operant ethanol self-administration by high-alcohol-drinking replicate rat lines. Alcohol. 2006; 38:155-164. [PubMed: 16905441]

Overstreet DH, Rezvani AH, Cowen M, Chen F, Lawrence AJ. Modulation of high alcohol drinking in the inbred Fawn-Hooded (FH/Wjd) rat strain: Implications for treatment. Addiction Biology. 2006; 11:356-373. [PubMed: 16961764]

Pitkänen T, Lyyra AL, Pulkkinen L. Age of onset of drinking and the use of alcohol in adulthood: a follow-up study from age 8-42 for females and males. Addiction. 2005; 100:652-661. [PubMed: 15847623]

Plant, M.; Plant, M. Binge Britain: Alcohol and the national response. New York: Oxford University Press; 2006.

Quine S, Stephenson JA. Predicting smoking and drinking intentions and behavior of pre-adolescents: The influence of parents, siblings, and peers. Family Systems Medicine. 1990; 8:191-200. 
Quintanilla ME, Israel Y, Sapag A, Tampier L. The UChA and UChB rat lines: metabolic and genetic differences influencing ethanol intake. Addiction Biology. 2006; 11:310-323. [PubMed: 16961761]

Research Society on Alcoholism. Impact of Alcoholism and Alcohol Induced Disease on America. Austin, TX: Research Society on Alcoholism; 2009.

Rodd ZA, Bell RL, Kuc KA, Murphy JM, Lumeng L, Li TK, et al. Effects of repeated alcohol deprivations on operant ethanol self-administration by alcohol-preferring $(\mathrm{P})$ rats. Neuropsychopharmacology. 2003; 28:1614-1621. [PubMed: 12799615]

Russell RN, McBride WJ, Lumeng L, Li TK, Murphy JM. Apomorphine and 7-OH DPAT reduce ethanol intake of $P$ and HAD rats. Alcohol. 1996; 13:515-519. [PubMed: 8888949]

Samson HH, Files FJ, Denning C, Marvin S. Comparison of alcohol-preferring and nonpreferring selectively bred rat lines. I. Ethanol initiation and limited access operant self-administration. Alcoholism: Clinical and Experimental Research. 1998; 22:2133-2146.

Simms JA, Steensland P, Medina B, Abernathy KE, Chandler LJ, Wise R, et al. Intermittent access to $20 \%$ ethanol induces high ethanol consumption in Long-Evans and Wistar rats. Alcoholism: Clinical and Experimental Research. 2008; 32:1816-1823.

Sinclair JD, Li TK. Long and short alcohol deprivation: Effects on AA and P alcohol-preferring rats. Alcohol. 1989; 6:505-509. [PubMed: 2597353]

Sommer W, Hyytiä P, Kiianmaa K. The alcohol-preferring AA and alcohol-avoiding ANA rats: neurobiology of the regulation of alcohol drinking. Addiction Biology. 2006; 11:289-309. [PubMed: 16961760]

Spear, LP. The Behavioral Neuroscience of Adolescence. New York: W.W. Norton; 2010.

Stromberg MF, Mackler SA, Volpicelli JR, O'Brien CP. Effect of acamprosate and naltrexone, alone or in combination, on ethanol consumption. Alcohol. 2001; 23:109-116. [PubMed: 11331108]

Tampier L, Quintanilla ME. Effect of ethanol deprivation and re-exposure on the ethanol drinking behaviour of the high-alcohol-drinker (UChB) rats. Journal of Behavioral and Brain Science. $2011 ; 1: 1-5$.

Toalston JE, Oster SM, Kuc KA, Pommer TJ, Murphy JM, Lumeng L, et al. Effects of alcohol and saccharin deprivations on concurrent ethanol and saccharin operant self-administration by alcoholpreferring (P) rats. Alcohol. 2008; 42:277-284. [PubMed: 18400451]

Warnock KT, Yang AR, Yi HS, June HL Jr, Kelly T, Basile AS, et al. Amitifadine, a triple monoamine uptake inhibitor, reduces binge drinking and negative affect in an animal model of cooccurring alcoholism and depression symptomatology. Pharmacology, Biochemistry, and Behavior. 2012; 103:111-118.

Wechsler H, Lee JE, Kuo M, Lee H. College binge drinking in the 1990s: a continuing problem. Results of the Harvard School of Public Health 1999 College Alcohol Study. Journal of American College Health. 2000; 48:199-210. [PubMed: 10778020]

Wechsler H, Nelson TF. Relationship between level of consumption and harms in assessing drink cutpoints for alcohol research: Commentary on "Many college freshman drink at levels far beyong the binge threshold" by White et al. Alcoholism: Clinical and Experimental Research. 2006; 30:922-927.

West MW, Biggs TA, Schreiber R, De Vry J, Myers RD. Calcium channel agonist (-)-BAY k 8644 suppresses free and limited access intake of alcohol in genetic drinking rats. Psychopharmacology. 1999; 142:261-269. [PubMed: 10208318]

West MW, Kalmus G, Myers RD. Limited access to ethanol in genetic drinking rats is suppressed while feeding is enhanced by the mixed 5-HT1A agonist/5-HT2A antagonist FG5938. Pharmacology, Biochemistry, and Behavior. 1998; 60:823-828.

White AM, Kraus CL, Swartzwelder H. Many college freshmen drink at levels far beyond the binge threshold. Alcoholism: Clinical and Experimental Research. 2006; 30:1006-1010.

Winters, KC. Assessing adolescent substance use problems and other areas of functioning: state of the art. In: Monti, PM.; Colby, SM.; O’Leary, TA., editors. Adolescents, Alcohol, and Substance Abuse: Reaching Teens through Brief Interventions. New York: Guilford Press; 2001. p. 80-108. 
Zahr N, Mayer D, Rohlfing T, Hsu O, Vinco S, Orduna J, et al. Rat strain differences in brain structure and neurochemistry in response to binge alcohol. Alcoholism: Clinical and Experimental Research. 2013 In Press.

Zalewska-Kaszubska J, Gorska D, Dyr W, Czarnecka E. Voluntary alcohol consumption and plasma beta-endorphin levels in alcohol-preferring rats chronically treated with naltrexone. Physiology \& Behavior. 2008; 93:1005-1010. [PubMed: 18262210] 


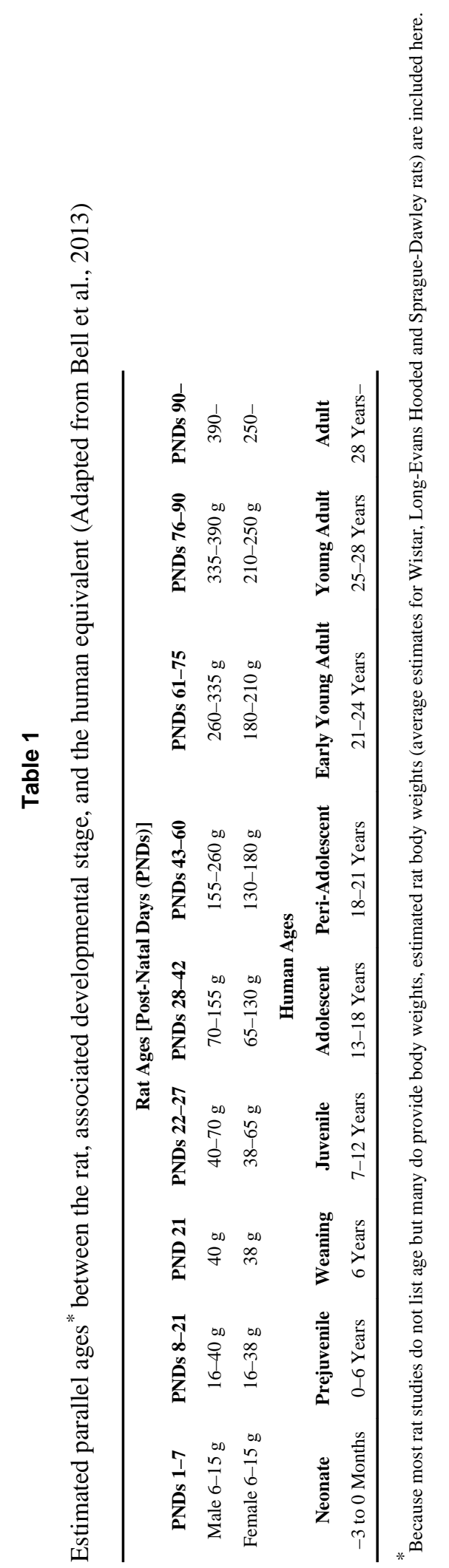




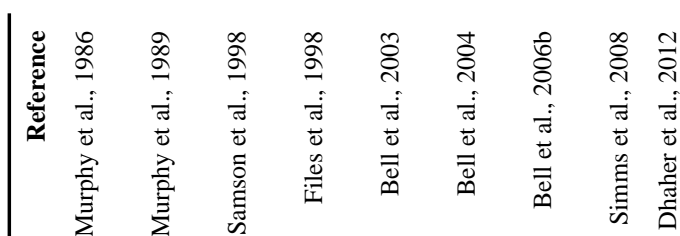

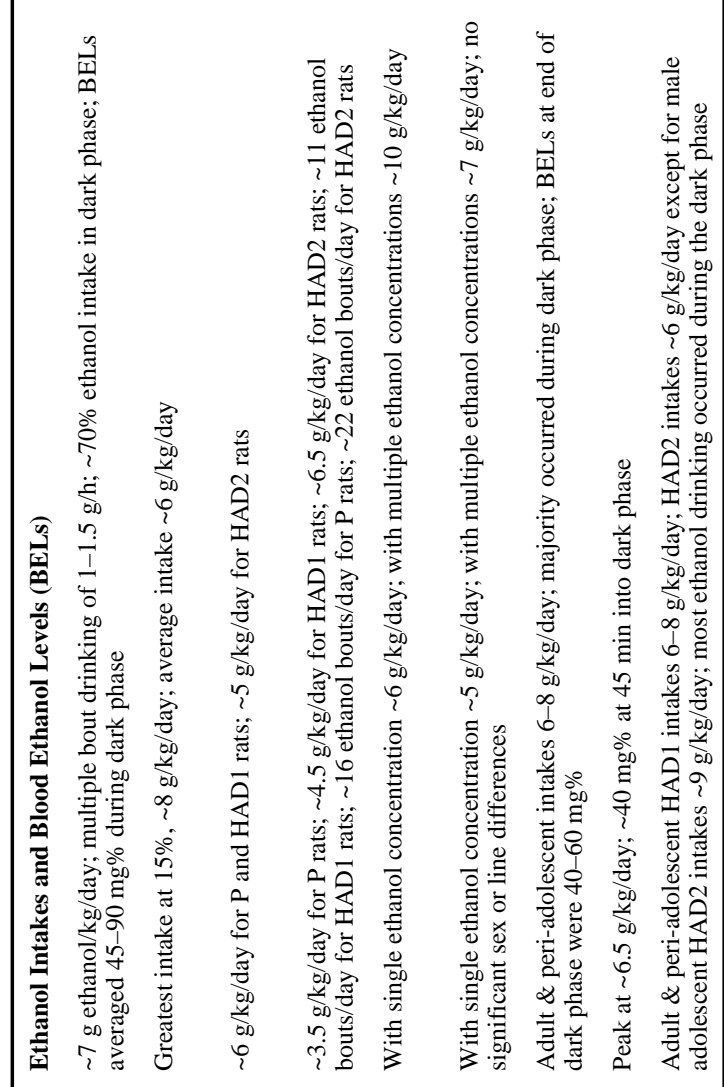




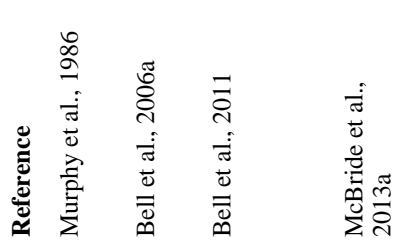

to

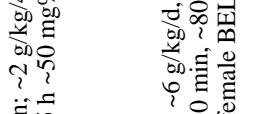

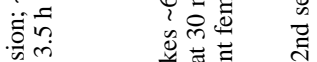

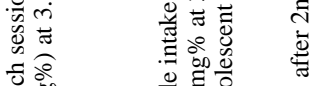

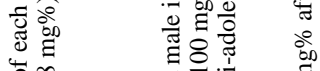

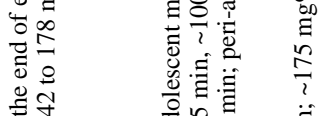

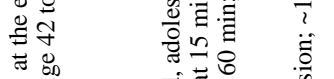

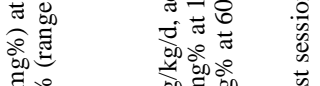

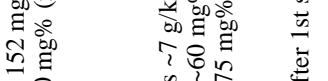

产 y

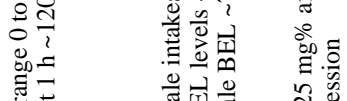

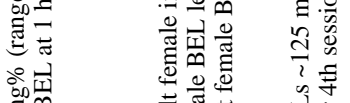

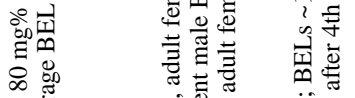




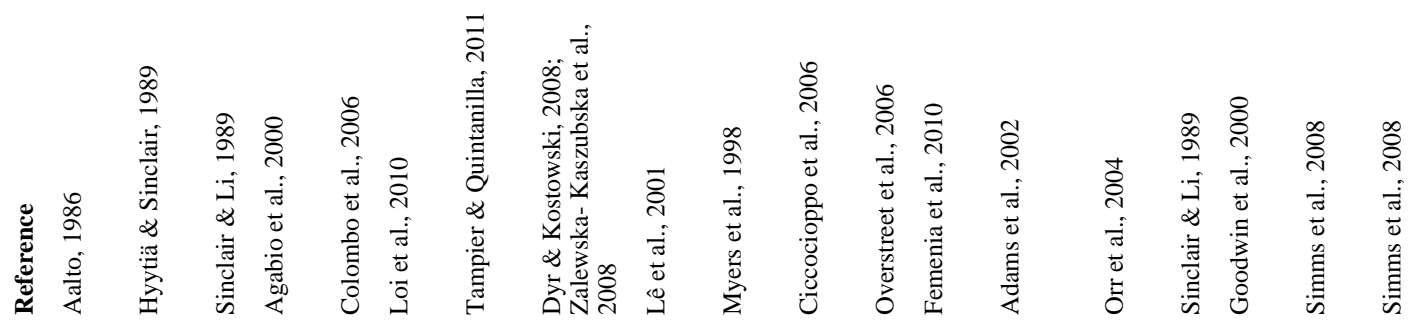

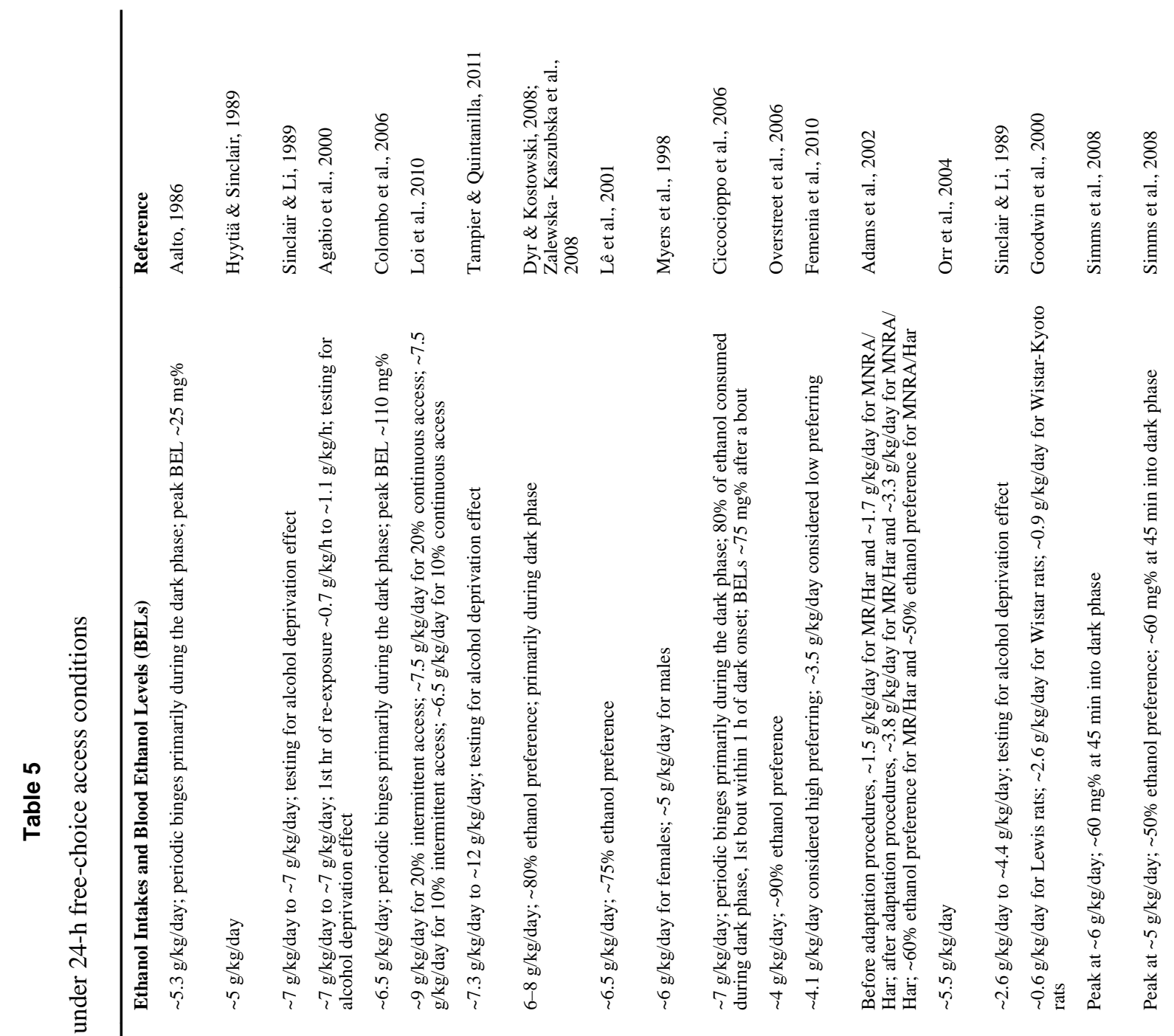

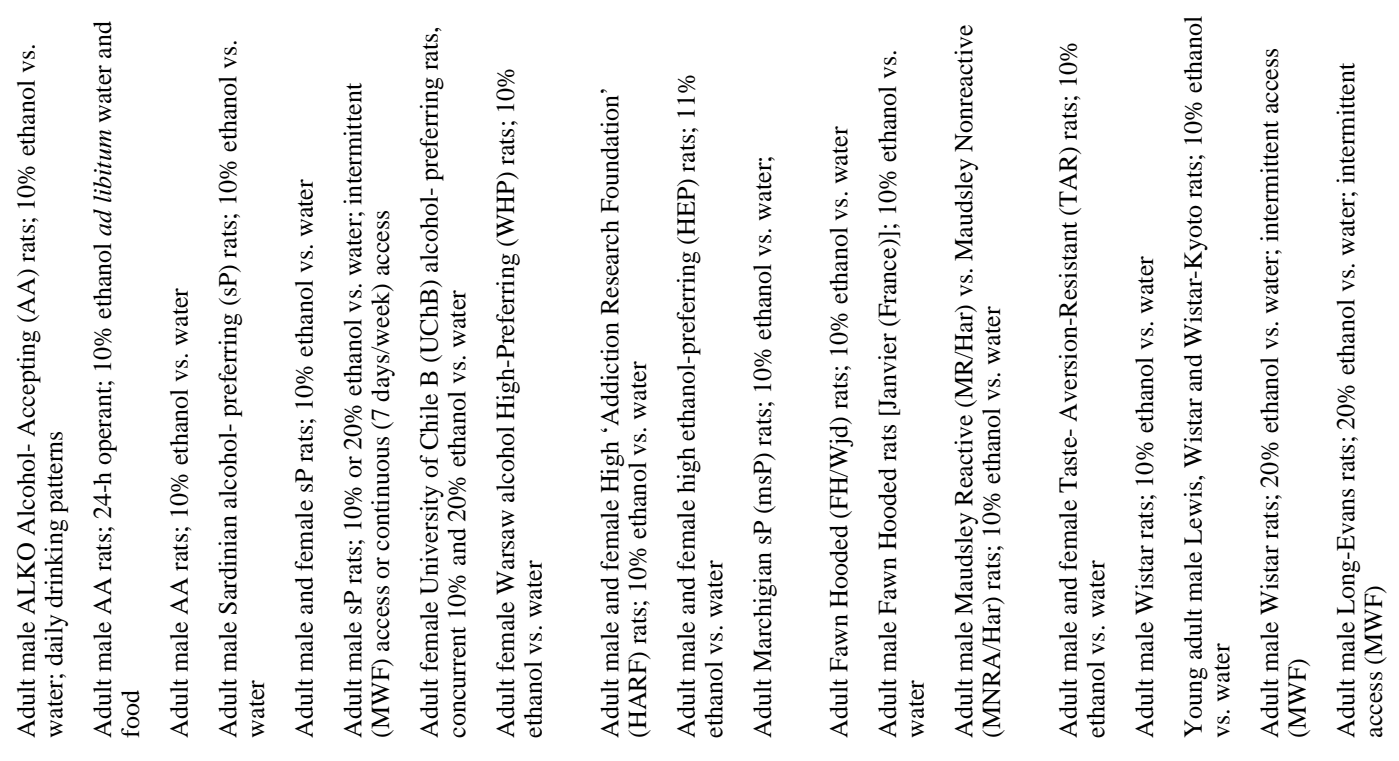




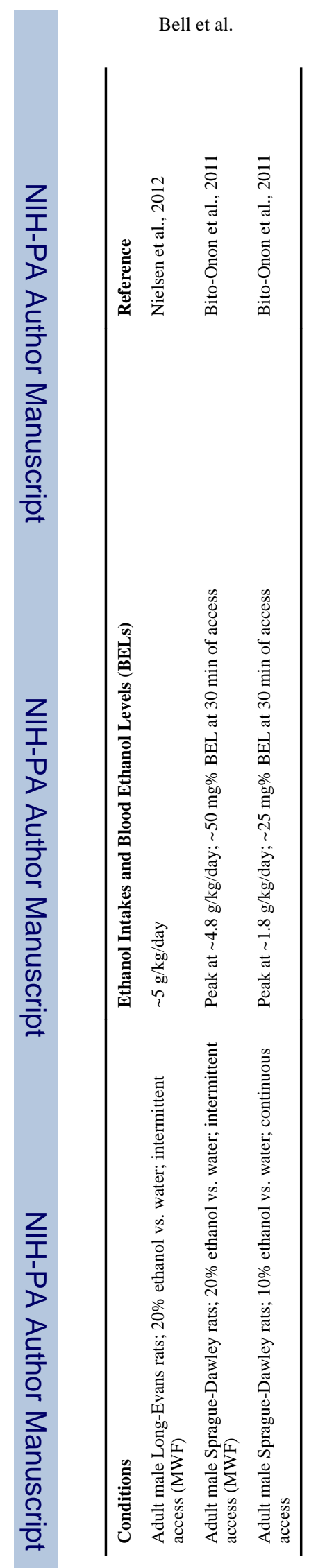

Page 22 


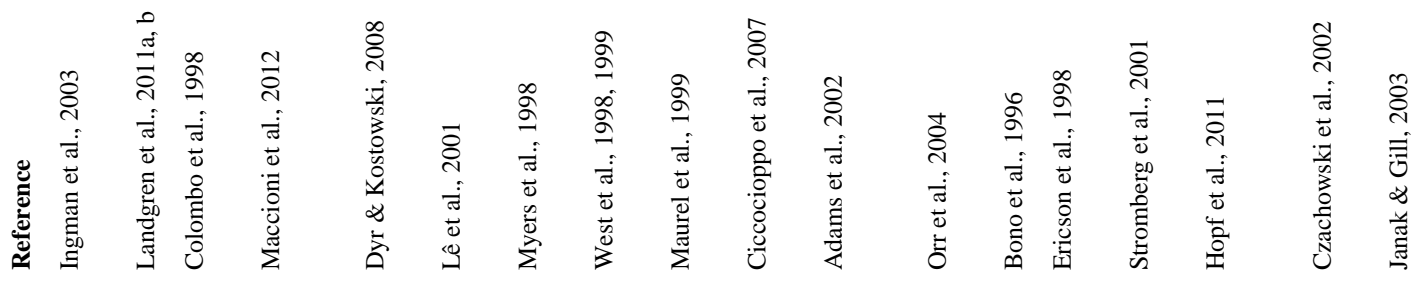
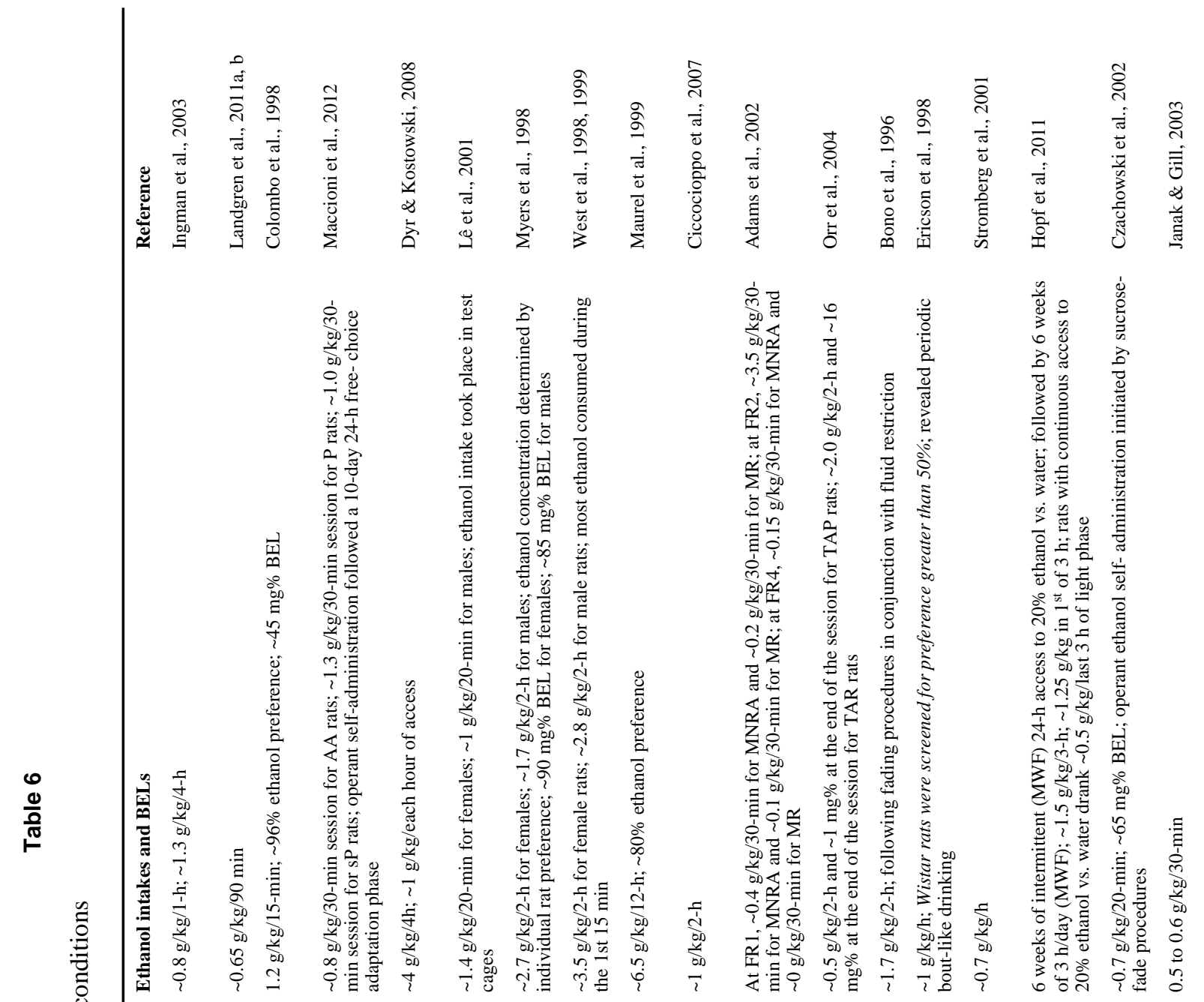
Bell et al.

Page 24

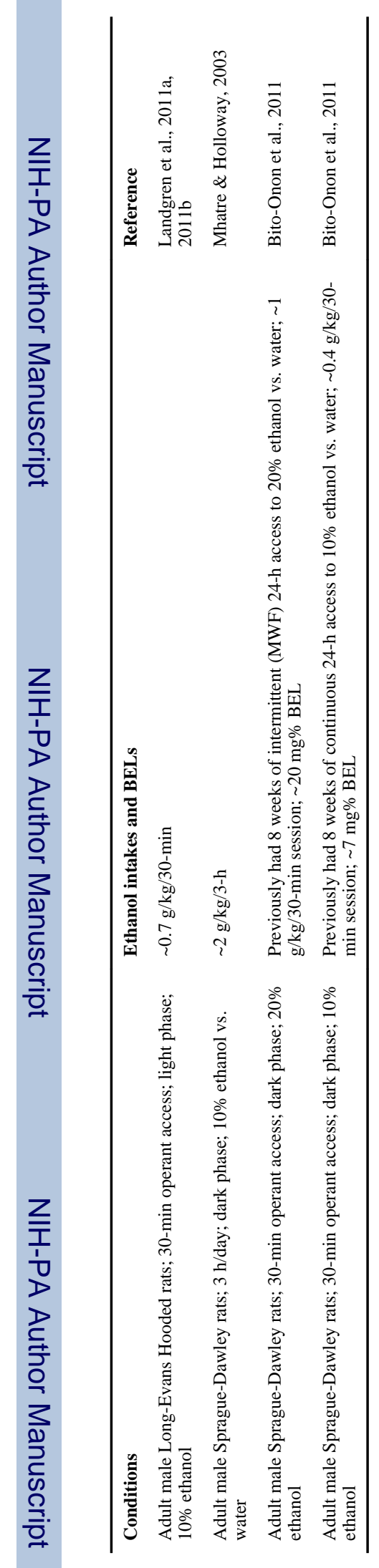

Alcohol. Author manuscript; available in PMC 2015 May 01. 